\title{
Pengaruh Ekstrak Bawang Dayak (Eleutherine palmifolia (L), Merr) terhadap Neutrophil Lymphocyte Ratio (NLR) pada Mencit Balb/C yang Diinfeksi Salmonella Typhimurium
}

\author{
Effect of Dayak Onion Extract (Eleutherine palmifolia (L), Merr) on Neutrophil Lymphocyte Ratio \\ (NLR) in Balb / C Mice Infected with Salmonella Typhimurium
}

\author{
Arum Kartikadewi ${ }^{1}$, Ardhea Jaludamascena ${ }^{2}$ \\ ${ }^{1}$ Departemen Anatomi, Universitas Muhammadiyah Semarang \\ ${ }^{2}$ Laboratorium Patologi Klinik RS Dr Kariadi Semarang \\ *Penulis Korespondensi. Email: dr.arumkartikadewi@gmail.com
}

\begin{abstract}
Abstrak
Latar Belakang: Rasio netrofil limfosit merupakan parameter yang mudah dan murah untuk mengukur respon inflamasi terhadap Salmonela thypimurium. Bawang dayak (Eleutherine palmifolia (L.) Merr) secara empiris digunakan untuk obat antibakteri dan anti inflamasi karena kandungan flavonoidnya. Penelitian bertujuan membuktikan pengaruh pemberian ekstrak bawang dayak terhadap Netrofil limfosit rasio (NLR) Mencit Balb/C yang dinfeksi Salmonella typimurium.

Metode: Desain penelitian adalah observasional analitik dengan pendekatan cross-sectional. Penelitian dilakukan dengan menilai preparat sediaan apus darah tepi penelitian sebelumnya. Sediaan apus darah tepi didapatkan dari 24 ekor tikus yang terbagi menjadi 4 kelompok perlakuan yaitu 3 kelompok tikus yang diinfeksi Salmonella typhimurium dosis 105CFU secara intraperitoneal $(\mathrm{K}+, \mathrm{P} 1 \mathrm{dan} \mathrm{P} 2)$ dan 1 kelompok yang tidak diberikan perlakuan apapun (K-). K+ tidak diterapi, P1 diterapi ekstrak umbi bawang dayak dosis 3,03mg/20gr.BB dan P2 diterapi dengan dosis6,06 mg/20gr.BB selama 7 hari. Treatment diberikan 1 kali/ perhari, 12 jam paska infeksi Salmonella typhimurium. Jumlah neutrofil dan jumlah limfosit didapatkan dengan penghitungan manual. Nilai NLR adalah jumlah neutrofil dibagi jumlah limfosit. Beda rerata NLR dianalisis dengan one way anova dilanjutkan dengan post hoc LSD

Hasil: Rerata NLR tiap kelompok adalah (K-): 1,03+ 0,09; (K+): 1,35+0,18;( P1): 0,86+0,05 dan (P2): 1,19 +0,22. Rerata NLR antar kelompok berbeda bermakana $(\mathrm{p}=0,001)$. Perbedaan tersebut terlihat jelas di antara kelompok K- dan $\mathrm{K}+(\mathrm{p}=0,002)$; antara kelompok $\mathrm{P} 1$ dan $\mathrm{K}+(\mathrm{p}=0,001)$ dan antara kelompok $\mathrm{P} 1$ dengan $\mathrm{P} 2(\mathrm{p}=0,01)$.

Kesimpulan: Pemberian ekstrak bawang dayak dosis 3,03 $\mathrm{mg} / 20 \mathrm{gr}$.BB berpengaruh terhadap NLR mencit BALB/C yang diinfeksi

Salmonela thypimurrium.
\end{abstract}

Kata Kunci: Bawang Dayak, NLR, Salamonella thypimurrium.

\begin{abstract}
Background: The neutrophil lymphocyte ratio is an easy and inexpensive parameter for measuring the inflammatory response to Salmonella thypimurium. Dayak onion (Eleutherine palmifolia (L.) Merr) is empirically used for antibacterial and anti-inflammatory drugs because of its flavonoid content. The aim of this study was to prove the effect of onion dayak extract on Netrophil lymphocyte ratio (NLR) Balb / C mice infected with Salmonella typimurium. Method: The study design was observational analytic with a cross-sectional approach. The study was conducted by assessing previous blood smear smear preparations. Edge blood smear was obtained from 24 rats divided into 4 treatment groups, namely 3 groups of rats infected with 105CFU Salmonella typhimurium dose intraperitoneally $(K+, P 1$ and $P 2)$ and 1 group not given any treatment $(K-) . K+$ was not treated, $P 1$ was treated with dayak onion tuber extract dose 3.03mg / 20gr.BB and P2 treated with a dose of $6.06 \mathrm{mg} / 20 \mathrm{gr} . \mathrm{BB}$ for 7 days. Treatment is given 1 time / day, 12 hours after Salmonella typhimurium infection. The number of neutrophils and the number of lymphocytes obtained by manual calculation. NLR value is the number of neutrophils divided by the number of lymphocytes. The difference in average NLR is analyzed by one way ANOVA followed by post hoc LSD

Result: The mean NLR for each group is $(K-): 1.03+0.09 ;(K+): 1.35+0.18$; $(P 1): 0.86+0.05$ and $(P 2): 1.19+0.22$. The mean NLR between different groups of meals $(p=0.001)$. This difference is clearly seen between the $K$ - and $K+$ groups $(p=0.002)$; between groups $P 1$ and $K+(p=0.001)$ and between groups $P 1$ with $P 2(p=0.01)$.

Conclusion: The administration of $3.03 \mathrm{mg} / 20 \mathrm{gr} . B B$ dayak onion extract influences the NLR of infected BALB / C mice Thypimurrium Salmonella.
\end{abstract}

Keywords: Dayak Onions, NLR, Salmonella typhimurium. 


\section{PENDAHULUAN}

Infeksi Salmonella thypi masih merupakan masalah kesehatan di Indonesia. Prevalensi Infeksi Salmonella sp menempati urutan ke 3 setelah India dan Pakistan yaitu sekitar 81,7 kasus per 100.000 penduduk dari semua umur setiap tahunnya. ${ }^{1,2,3}$ Infeksi Salmonella typhimurium pada manusia menyebabkan gastroenteritis dengan gejala diare akut diikuti dengan bakteremia yang dapat menimbulkan sepsis, terutama pada pasien dengan gangguan sistem imun., ${ }^{2,4}$

Infeksi Salmonella typhimurium pada model tikus menunjukkan respon imun yang stereotipik seperti pada infeksi bakteri lainnya yaitu gambaran inflamasi eksudatif yang dimotori oleh neutrofil. Adanya infeksi Salmonella typhimurium menyebabkan mobilisasi neutrofil menuju tempat infeksi sebagai pertahanan imun utama melawan infeksi bakteri. $^{5}$ Infeksi Salmonella typhimurium mengaktivasi produksi IL-8 yang berperan sebagai kemoatraktan terhadap neutrofil. Infeksi Salmonella typhimurium juga mengaktifkan aksis IL-12/IFN- $\gamma$ yang merupakan sistem regulasi imun utama yang menghubungkan sistem imun bawaan dengan sistem imun adaptif. Aktivasi aksis IL-12/IFN $\gamma$ akan mengaktifkan limfosit untuk memproduksi IFN- $\gamma$ yang pada akhirnya akan meningkatkan kemampuan fagositosis makrofag dan neutrofil.., 7

Neutrophil-lymphocyte ratio (NLR) merupakan parameter yang murah dan mudah serta dapat diketahui dari hasil pemeriksaan darah rutin di laboratorium. Penggunaan NLR saat ini sebagai petanda inflamasi mempunyai korelasi yang baik dengan C-reactive protein (CRP), sehingga NLR dianggap lebih mudah dan murah dibandingkan mengukur CRP. Penelitian Lou et al, 2015. menunjukkan bahwa NLR lebih superior sebagai marker inflamasi dibandingkan dengan parameter leukosit yang lain karena mempunyai stabilitas yang lebih baik. ${ }^{8}$ NLR pada keadaan fisiologis adalah $<5$, dan akan mengalami peningkatan $>6$ pada keadaan patologi seperti infeksi berat atau Systemic inflamatoy respon syndrome (SIRS). ${ }^{9}$ Holub et al menyimpulkan bahwa NLR dengan cutoff 6,2 mempunyai sensitivitas $91 \%$ dan spesifisitas $96 \%$ untuk pasien bakteremia. ${ }^{9}$ Penelitian Jager et al, 2010 menunjukkan NLR dapat menjadi prediktor bakteremia pasien di ruang rawat gawat darurat. ${ }^{10}$

Bawang dayak (Eleutherine palmifolia (L.) Merr) merupakan tanaman khas Kalimantan yang telah digunakan secara turun temurun oleh masyarakat Dayak sebagai obat untuk mengatasi berbagai penyakit seperti diare, darah tinggi, kencing manis, bisul dan sebagainya. Hal ini disebabkan karena adanya senyawa fenolik dan flavonoid yang terkandung dalam umbi bawang dayak. Beberapa penelitian menunjukkan bahwa senyawa fenolik dan flavonoid memiliki potensi sebagai antioksidan, antiinflamasi dan imunomodulasi. Senyawa fenolik dan flavonoid dapat mempengaruhi sitokin proinflamasi yang pada akhirnya akan mempengaruhi NLR dengan mengubah proporsi jumlah neutrofil dan limfosit yang berperan sebagai imunitas bawaan (innate) dan adaptif (acquired). ${ }^{11,12,13}$ Potensi yang dimiliki bawang dayak (Eleutherine palmifolia (L.) Merr) sebagai tanaman obat sangat besar namun penelitian yang mengkaji efeknya terhadap NLR masih belum banyak dilakukan. Penelitian ini bertujuan untuk mengetahui efek dari ekstrak umbi bawang dayak terhadap nilai NLR mencit Balb /C yang terinfeksi Samonella thypimurium.

\section{METODE}

\section{Sampel Penelitian}

Sampel yang digunakan pada penelitian ini adalah sediaan apus darah tepi yang didapat dari database Laboratorium Biomedik UNIMUS, atas persetujuan dari peneliti sebelumnya yaitu Agysha dan Tsani, 2017. Sediaan darah apus tepi tersebut sudah diberi tanda sesuai dengan kelompok perlakuan dari penelitian sebelumnya. Jumlah sediaan apus darah tepi yang digunakan sebagai penelitian berjumlah 24 slide, yang terbagi atas 4 kelompok penelitian yaitu $\mathrm{K}(-)$. 
$\mathrm{K}(+), \quad \mathrm{P} 1$ dan $\mathrm{P} 2$ sesuai penelitian sebelumnya. ${ }^{14,15}$

\section{Alat dan Bahan}

Alat yang digunakan pada penelitian ini adalah gelas ukur, pipet, mikroskop, hand tally counter dan alat tulis. Bahan yang digunakan pada penelitian ini adalah sediaan apus darah tepi, reagen pewarnaan Giemsa, aquades dan minyak emersi. Sediaan apus darah tepi yang didapat dari penelitian sebelumnya. ${ }^{14,15}$

\section{Cara Penelitian}

Penelitian ini adalah penelitian observasional dengan pendekatan crosssectional terhadap sediaan apus darah tepi dari penelitian sebelumnya yang meneliti pengaruh ekstrak bawang dayak terhadap jumlah limfosit dan monosit pada mencit Balb/c jantan yang diinfeksi Salmonella typhimurium. Penelitian telah dilaksanakan di Laboratorium Biomedik FK UNIMUS. Penelitian dilakukan dengan menilai preparat sediaan apus darah tepi dari penelitian sebelumnya dimana sediaan apus darah tepi didapatkan dari 24 ekor tikus yang terbagi menjadi 4 kelompok perlakuan yaitu 3 kelompok tikus yang diinfeksi Salmonella typhimurium dosis 105CFU secara intraperitoneal $(\mathrm{K}+, \mathrm{P} 1$ dan $\mathrm{P} 2)$ dan 1 kelompok yang tidak diberikan perlakuan apapun (K-). Kelompok P1 diberi tambahan ekstrak umbi bawang dayak dengan dosis $3,03 \mathrm{mg} / 20$ gr.BB dan kelompok P2 diberi ekstrak umbi bawang dayak dengan dosis $6,06 \mathrm{mg} / 20 \mathrm{gr}$.BB selama 7 hari, sehari $1 \mathrm{kali}$ dimulai 12 jam paska infeksi Salmonella typhimurium dengan cara sondase. ${ }^{14,15}$

Semua sediaan apus darah tepi sudah difiksasi dan diwarnai pada penelitian sebelumnya untuk kemudian dilakukan pemeriksaan hitung jenis leukosit. Pemeriksaan hitung jenis leukosit yang dilakukan adalah pemeriksaan hitung jenis metode manual, yaitu dengan cara menghitung jumlah setiap jenis leukosit (basofil, eosinofil, neutrofil, limfosit dan monosit) dari 100 leukosit yang ditemukan pada zona baca preparat sediaan apus darah tepi, menggunakan mikroskop dengan perbesaran 40x objektif. Jumlah setiap jenis leukosit yang ditemukan dilaporkan dalam satuan persentase. ${ }^{16}$

\section{Pengumpulan Data}

Data yang dikumpulkan pada penelitian ini adalah data jumlah neutrofil, jumlah limfosit dan NLR. Jumlah neutrofil dan limfosit yang didapat dari pemeriksaan hitung jenis leukosit. Nilai NLR pada penelitian ini didapat dengan cara membagi persentase jumlah neutrofil dibagi persentase jumlah limfosit. ${ }^{17}$ NLR tidak memiliki satuan.

\section{Analisis Data}

Data yang terkumpul diolah menggunakan program komputer. Analisis data meliputi analisis diskriptif (distribusi, frekuensi dan rerata) dan uji hipotesis. Semua data numerik dilakukan uji statistik untuk mengetahui normalitas data menggunakan uji normalitas Saphiro-Wilk karena sampel kurang dari 50. Data dikatakan normal jika uji Saphiro-Wilk menunjukkan $\mathrm{p}>0,5$. Data yang ada kemudian diuji dengan menggunakan uji statistik One Way ANOVA, kemudian dilanjutkan dengan uji post hoc LSD. Data yang berdistribusi normal ditampilkan dalam bentuk rerata + SB. Signifikansi statistik dinyatakan apabila $\mathrm{p}<0,05$.

\section{HASIL}

Pengamatan telah dilakukan pada sediaan apus darah tepi di Laboratorium Biomedik UNIMUS pada periode bulan September hingga November 2018. Analisis deskriptif dilakukan untuk mengetahui secara umum gambaran variabel hasil penelitian yang telah dilakukan. Analisis deskriptif data penelitian dapat dilihat pada Tabel 1 .

Berdasarkan Tabel 1, didapatkan rerata jumlah neutrofil tertinggi pada kelompok $\mathrm{K}+$ yaitu $56 \%$, sedangkan rerata jumlah neutrofil terendah pada kelompok P1 dengan rerata $44,5 \%$. Rerata jumlah limfosit tertinggi didapatkan pada kelompok P1 dengan rerata $52,83 \%$, sedangkan rerata jumlah limfosit 
terendah didapatkan pada kelompok $\mathrm{K}+$ dengan rerata $41,83 \%$. Nilai NLR tertinggi didapatkan pada kelompok $\mathrm{K}+$ yaitu 1,35 dan nilai NLR terendah didapatkan pada kelompok P1 yaitu 0,86 .

Tabel 1. Analisis Deskriptif Data Penelitian

\begin{tabular}{|c|c|c|}
\hline Variabel & Kelompok & Mean $( \pm S D)$ \\
\hline \multirow{3}{*}{$\begin{array}{l}\text { Jumlah neutrofil } \\
\qquad(\%)\end{array}$} & $\mathrm{K}-$ & $50,17(2,23)$ \\
\hline & $\begin{array}{c}\mathrm{K}+ \\
44,50(1,76)\end{array}$ & $56,00(2,83) \mathrm{P} 1$ \\
\hline & $\mathrm{P} 2$ & $53,50(5,32)$ \\
\hline \multirow{3}{*}{$\begin{array}{c}\text { Jumlah limfosit } \\
(\%)\end{array}$} & $\mathrm{K}-$ & $48,67(2,34)$ \\
\hline & $\begin{array}{c}\mathrm{K}+ \\
52,83(2,14)\end{array}$ & $41,83(3,31) \mathrm{P} 1$ \\
\hline & $\mathrm{P} 2$ & $45,83(4,45)$ \\
\hline \multirow{3}{*}{ NLR } & $\mathrm{K}-$ & $1,03(0,09)$ \\
\hline & $\mathrm{K}+$ & $1,35(0,18) \mathrm{P} 1$ \\
\hline & $\mathrm{P} 2$ & $1,19(0,22)$ \\
\hline
\end{tabular}

Hasil uji normalitas data NLR menunjukkan data berdistribusi normal sehingga analisis data penelitian dilanjutkan dengan uji One Way ANOVA untuk mengetahui perbedaan nilai NLR antar kelompok penelitian. Hasil uji statistik terhadap data NLR disajikan pada Tabel 2.
Berdasarkan Tabel 2, hasil uji statistik terhadap data NLR didapatkan $\mathrm{p}=0,001$ yang artinya didapatkan perbedaan NLR yang bermakna diantara kelompok perlakuan. Uji statistik dilanjutkan dengan uji post hoc LSD untuk mengetahui lebih detil perbedaan nilai NLR diantara kelompok perlakuan. Tabel 3 menunjukkan hasil uji post hoc LSD terhadap data

NLR.

Tabel 2. Hasil Uji Statistik NLR

\begin{tabular}{cccc}
\hline Variabel & Kelompok & Mean $( \pm$ SD $)$ & $\mathrm{p}^{*}$ \\
\hline \multirow{3}{*}{ NLR } & $\mathrm{K}-$ & $1,03(0,09)$ & \\
& $\mathrm{K}+$ & $1,35(0,18)$ & 0.001 \\
& $\mathrm{P} 1$ & $0,86(0,05)$ & \\
& $\mathrm{P} 2$ & $1,19(0,22)$ & \\
\hline
\end{tabular}

Tabel 3. Hasil Uji Post Hoc NLR

\begin{tabular}{cccc}
\hline Kelompok & $\mathrm{K}+$ & $\mathrm{P} 1$ & $\mathrm{P} 2$ \\
\hline $\mathrm{K}-$ & $0,002^{*}$ & 0,062 & 0,103 \\
$\mathrm{~K}+$ & - & $0,001^{*}$ & 0,080 \\
$\mathrm{P} 1$ & - & - & $0,001^{*}$ \\
\hline
\end{tabular}

*Diuji dengan uji LSD, signifikansi p<0,05

Tabel 3 menunjukkan adanya perbedaan NLR yang bermakna antara kelompok $\mathrm{K}$ - dengan $\mathrm{K}+(\mathrm{p}=0,002)$, antara kelompok $\mathrm{K}+$ dengan $\mathrm{P} 1 \quad(\mathrm{p}=0,001)$ dan antara kelompok P1 dengan P2 $(\mathrm{p}=0,001)$. 


\section{PEMBAHASAN}

Rerata nilai NLR pada kelompok $\mathrm{K}+$ secara signifikan lebih tinggi dibandingkan kelompok K-, hal tersebut membuktikan adanya pengaruh infeksi Salmonella typhimurium terhadap nilai NLR. Hal ini sesuai dengan penelitian-penelitian terdahulu dimana adanya infeksi Salmonella typhimurium akan menyebabkan terjadinya peningkatan Interleukin-8 (IL-8) yang berakibat adanya migrasi neutrofil antar kompartemen. Bakteri Salmonella typhimurium juga mengaktivasi limfosit untuk memproduksi IL-17 yang selanjutnya akan menstimulasi produksi Granulocyte colony stimulating factor (G-CSF) dan Granulocyte macrophage collony stimullating factor (GM-CSF) di sumsum tulang yang akhirnya akan meningkatkan jumlah neutrofil dalam darah dan mengubah proporsi leukosit lainnya sehingga nilai NLR akan mengalami kenaikan. ${ }^{2,18,19,20}$

Rerata nilai NLR pada kelompok P1 secara signifikan lebih rendah dibandingkan kelompok $\mathrm{K}+$, hal tersebut membuktikan adanya pengaruh ekstrak umbi Bawang Dayak (Eleutherine palmifolia (1), Merr) terhadap nilai NLR yang sudah terpengaruh infeksi Salmonella typhimurium. Hal ini sesuai dengan penelitian sebelumnya mengenai efek imunomodulator Bawang Dayak, dimana kandungan senyawa fenolik dan flavonoid pada ekstrak umbi Bawang Dayak (Eleutherine palmifolia (1), Merr) dapat meningkatkan produksi IL-2 yang terlibat dalam aktivasi dan proliferasi limfosit dengan cara penghambatan terhdap signalling sitokin proinflamasi IL-17. Penurunan kadar IL-17 akan menurunkan kadar G-CSF dan GM-CSF di sumsum tulang sehingga terjadi penurunan jumlah neutrofil.

$$
11,20,22,23
$$

Penurunan jumlah neutrofil disertai peningkatan jumlah limfosit akan menyebabkan nilai NLR yang rendah. Flavonoid juga dapat menstimulasi Interferon $\gamma$ (IFN- $\gamma$ ) yang meningkatkan kemampuan fagositosis makrofag dan neutrofil sehingga mempercepat berakhirnya proses inflamasi dan menurunkan kembali nilai NLR. ${ }^{22}$

Pada P2 pemberian dosis $60,6 / 20 \mathrm{mg}$ BB ekstrak bawang dayak tidak berhasil menurunkan NLR. Kandungan Bawang dayak sebagai anti inflamasi tidak sejalan antara dosis dan efek. Meskipun flavonoid efektif untuk anti infeksi, anti inflamasi, namun bioavailabilitas dalam tubuh kurang baik. Flavonoid mengalami dua kali metabolisme, yaitu metilasi, sulfatasi, dan glukoronoidasi di hepar dan usus. Flavonoid yang terkonjugasi juga di temukan dalam usus, sehingga mempengaruhi absorbsinya. ${ }^{24}$ Kemungkinan dengan konsentrasi tinggi, jumlah substrat yang berikatan dengan reseptor tidak sebanding, sehingga peningkatan dosis tidak memperbaiki efek. Kandungan ekstrak bawang dayak tidak tunggal. Dengan ekstraksi etanol zat yang terekstrak paling dominan adalah flavonoid, polifenol dan alkaloid. Metabolit sekunder dalam tanaman herbal dapat bekerja secara antagonis sinergi maupun potensiasi. Efek kerja antar komponen tersebut belum diketahui. ${ }^{25}$

Keterbatasan dalam penelitian ini adalah penelitian ini tidak menilai secara langsung kadar petanda inflamasi, penelitian ini juga hanya berlangsung 7 hari sehingga efek samping pemberian ekstrak Bawang Dayak mungkin belum dapat dinilai, penelitian ini menggunakan subyek penelitian mencit yang mana patofisiologinya tidak seluruhnya sama dengan manusia sehingga hasil penelitian ini tidak serta merta dapat langsung diaplikasikan kepada manusia.

Saran dari penelitian ini adalah perlu diadakan penelitian lebih lanjut dengan memperhatikan petanda inflamasi lainnya dengan waktu penelitian yang lebih lama dan juga pada subyek penelitian spesies yang lebih dekat dengan manusia agar hasil penelitiannya dapat diaplikasikan dengan lebih

optimal. 


\section{KESIMPULAN}

Pemberian ekstrak umbi bawang dayak (Eleutherine palmifolia (1), Merr) dapat berpengaruh terhadap neutrophil lymphocyte ratio (NLR) mencit BALB/c yang diinfeksi Salmonella typhimurium. Dosis ekstrak 3,03mg/20gr.BB efektif menurunkan NLR.

\section{UCAPAN TERIMAKASIH}

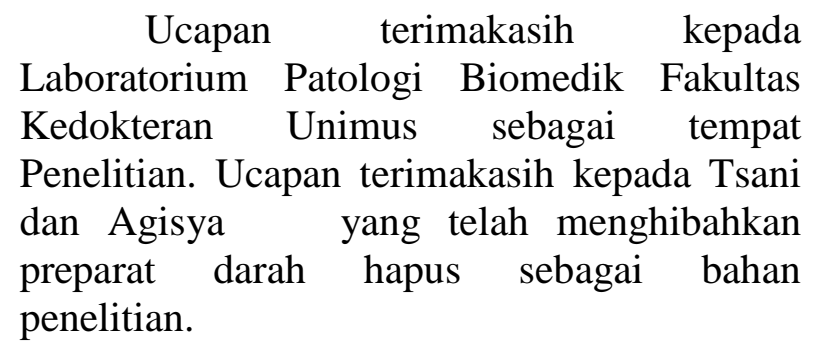

\section{REFERENSI}

1. Crump JA, Mintz ED. 'Global Trends in Typhoid and Paratyphoid Fever', Clinical Infectious Diseases. 2010;50(2), pp. 241246. doi: 10.1086/649541.

2. Raffatellu M, Inter SE, Wilson RP. 'Clinical pathogenesis of typhoid fever.', Journal of infection in developing countries. 2008; 2(4), pp. 260-266. doi: 10.3855/jidc. 219 .

3. Wain J, Hendriksen RS, Mikoleit ML, Ochilai LM. 'Typhoid fever', The Lancet. Elsevier Ltd, 2015; 385(9973), pp. 11361145 . doi: 10.1016/S01406736(13)62708-7.

4. Santos RL, Zhang S, Tsolis RM, Kingley RA. Baumler A J. 'Animal models of Salmonella infections: enteritis versus typhoid fever', Microbes and Infection. 2001; 3(14 15), pp. 1335-1344. doi: 10.1016/S1286 4579(01)01495-2.

5. Tükel Ç, Rafattellu M, Chessa D, Wilson RP, Akcelik M. 'Neutrophil influx during non- typhoidal salmonellosis: Who is in the driver's seat?', FEMS Immunology and Medical Microbiology. 2006; 46(3), pp. 320-329. doi: 10.1111/j.1574695X.2006.00051.x.

6. Bao S. Beagley KW, France MP, Shen C, Husband AJ. 'Interferon- c plays a critical role in intestinal immunity against Salmonella typhimurium infection, Immunology. 2001; 99, pp. 464-472.

7. Schuetze N, Schoeneberger S, Muller U, Freudenberg MA, Alber G, Straubinger RK. 'IL-12 family members: Differential kinetics of their TLR4-mediated induction by Salmonella Enteritidis and the impact of IL-10 in bone marrowderived macrophages', International Immunology. 2005; 17(5), pp. 649-659. doi: 10.1093/intimm/dxh247.

8. Lou M, Lou P, Tang R, Yu S, Huang W, He L. 'Relationship between neutrophillymphocyte ratio and insulin resistance in newly diagnosed type 2 diabetes mellitus patients'. BMC Endocrine Disorders. 2015; 15, pp. 4-9. doi: 10.1186/s12902015-0002-9.

9. Holup M, Beran O, Kasprikova N, Chalupa P. 'Neutrophil to lymphocyte count ratio as a biomarker of bacterial infections' Central European Journal of Medicine. 2012; 7(2), pp. 258-261. doi: 10.2478/s11536-012-0002-3.

10. de Jager CP, Van Wijk PT, Mathoera RB, de Jongh LJ, Van der Pol T, Wever PC. 'Lymphocytopenia and neutrophillymphocyte count ratio predict bacteremia better than conventional infection markers in an emergency care unit'. Critical Care. 2010; 14(5). doi: 10.1186/cc9309.

11. Kuntorini EM, Astuti MD. 'Penentuan Aktivitas Antioksidan Ekstrak Etanol Bulbus Bawang Dayak (Eleutherine americana Merr.)', Sains dan Terapan Kimia. 2010; 4(1), pp. 15-doi: 10.1073/pnas.0703993104

12. Early Febrinda A. 'Kapasitas Antioksidan Dan Inhibitor Alfa Glukosidase Ekstrak Umbi Bawang Dayak', Jurnal Teknologi dan Industri Pangan. 2013; 24(2), Doi:10.6066/jtip.2013.24. 2.161.

13. Ahmad I. Arifuddin M, Rijai L. 'The Effect of Extraction Methods of Bawang Dayak (Eleutherine Palmifolial MERR) Against TLC Profiles and Sunscreen 
Activities'. Pharmtech. 2016; 9(9), 42836.

14. Agysha N. Pengaruh Ekstrak Etanol Bawang Dayak (Eleutherine palmifolia) terhadap Jumlah Limfosit pada Mencit BALB/C yang Diinfeksi Salmonella typhimurium. Skripsi. 2017. Universitas Muhammadiyah Semarang.

15. Tsani M. Pengaruh Ekstrak Etanol Bawang Dayak (Eleutherine palmifolia) terhadap Jumlah Monosit pada Mencit BALB/C yang Diinfeksi Salmonella typhimurium. Skripsi. 2017. Universitas Muhammadiyah Semarang

16. Gandasoebrata R. Penuntun Laboratorium Klinik, 2008. Jakarta: Dian Rakyat.

17. Kučer N, Matijatko V, Kis I, Grden D, Brkljacic GM, Zvorc FZ, et al. 'White blood cell count and neutrophil to lymphocyte ratio in uncomplicated and complicated canine babesiosis caused by Babesia canis canis', Veterinarski arhiv. 2008; 78(4),. 321-30. Available at:http://www.staro.vef.unizg.hr/vetarhiv/ papers/2008-78-4-6.pdf.

18. Wright HL, Moots RJ, Bucknall RC, Erdward SW. 'Neutrophil function in inflammation and inflammatory diseases' Rheumatology. 2010; 49(9), 161831.doi:10.1093/ rheumatology/ keq045.

19. Broz P, Ohlson MB, Monack DM. 'Innate immune response to Salmonella typhimurium, a model enteric pathogen', Gut microbes. Landes Bioscience. 2012; 3(2), pp. 62-doi: 10.4161/gmic. 19141.

20. Mayadas TN, Cullere X, Lowell CA 'The Multifaceted Functions of Neutrophils', Annual review of pathology. 2014; 9, pp. 181-218. doi: 10.1146/annurev-pathol020712-164023.

21. Watson $\mathrm{CH}$, Edmunds WJ. 'A review of typhoid fever transmission dynamic models and economic evaluations of vaccination'. Vaccine. 2015. Elsevier Ltd. 33(S3), pp. C42-C54. doi:10.1016/j.vaccine.2015.04.013.

22. Kim HP, Son KH, Chang HW, Kang SS. 'Anti-inflammatory Plant Flavonoids and
Cellular Action Mechanisms', Journal of Pharmacological Sciences. 2004; 96(3), pp. 229-245. doi: 10.1254/jphs.CRJ04003X

23. Carmelita AB. ( 'Pengaruh Pemberian Ekstrak Etanol Umbi Bawang Dayak ( Eleutherine palmifolia ( L .) Merr . ) Secara Oral pada Mencit Balb / c Terhadap Pencegahan Penurunan Diameter Germinal Center pada Kelenjar Getah Bening Serta Kadar IgG Serum'. Jurnal Biosains Pascasarjana. 2016. 18(1).

24. Thilakaratna SH, Rupashinghe HPV. Flavonoid Bioavailability and Attemps for Bioavailability Enhancement. Nutrients. 2013;5(9):3367-87

25. Aronson JK. Concentration Effect and Dose Response Relation in Clinical Pathology. Br J Clin Pharmacol. 2007 Mar; 63(3): 255-257 